\title{
Nasal Cavity and Ethmoid Sinus Cancer pN3 TNM Finding v6 and v7
}

National Cancer Institute

\section{Source}

National Cancer Institute. Nasal Cavity and Ethmoid Sinus Cancer pN3 TNM Finding v6 and v7. NCI Thesaurus. Code C65067.

Nasal cavity and ethmoid sinus cancer with metastasis in a lymph node, more than $6 \mathrm{~cm}$ in greatest dimension. (from AJCC 6th and 7th Eds.) 